\title{
Arbeidsmiljø og selvmordsforebygging
}

\author{
Ved Ingrid Sivesind Mehlum og Lars Mehlum
}

\begin{abstract}
Arbeidsplassen har hittil i liten grad vaert sett på som en arena for selvmordforebyggende arbeid. For de fleste av oss er imidlertid arbeidsplassen det stedet vi oppholder oss mest ved siden av hjemmet. Arbeidet påvirker i stor grad livet til den enkelte, både fysisk, psykisk og sosialt, og arbeidsplassen er derfor viktig for den enkeltes triusel no helse.
\end{abstract}

I noen tilfeller er det en klar årsakssammenheng mellom belastninger i arbeidssituasjonen og selvmordshandlinger, men ofte ligger hovedårsakene utenfor arbeidsplassen. Likevel kan forhold ved arbeidssituasjonen være viktige som medvirkende årsaker. Uansett hvor årsaken måtte ligge, kan mye gjøres på arbeidsplassen for å forebygge selvmord slik at færrest mulig utvikler symptomer, risikoreaksjoner og sykdom (primærforebygging) (Mehlum og Mehlum 1999). Slik forebygging kan være lettere å gjennomføre i sammenheng med arbeidsplassen enn ellers i samfunnet, fordi forholdene innen en bransje eller på en arbeidsplass vil være forholdsvis homogene, med mindre variasjon $i$ miljøbelastninger og befolkningsgruppe. Samtidig vil mange arbeidsgivere og arbeidstakere være motiverte til å gjøre noe når de ser betydningen av forebygging for så vel velvære som produktivitet.

Sekundærforebygging av selvmord er imidlertid også viktig i en arbeidsplassammenheng. Dette er blitt fremhevet i Forsvarets selvmordsforebyggende program (Mehlum 1993), som omfatter alle ledd i forebyggingsarbeidet.

\section{Epidemiologi}

Hva vet vi om forekomst av selvmord og selvmordfors $\varnothing \mathrm{k}$ i forskjellige yrker?

En svensk undersøkelse som sammenliknet selvmordsraten i ulike yrkeskategorier i tidsspennet 1961-1979 viste høyere selvmordsfrekvens for menn i en rekke yrker med mindre kvalifikasjonskrav (f.eks. industri, handel og jordbruk) enn i yrker med høye krav til formelle kvalifikasjoner. Unntaket var helsepersonell, der det viste seg at leger av begge kjønn, mannlige tannleger, kvinnelige sykepleiere og hjelpepleiere hadde en høyere selvmordsrate enn gjennomsnittlig. Tilsvarende funn er gjort i land som Finland, Island, USA, England, Norge og en rekke andre land. Særlig har kvinnelige leger vist en sterkt forhøyet selvmordsrate. Hos leger ser det ut til at de sterkeste belastningene som utløser utbrenthet og selvmordsfare, er knyttet til pasientbe-

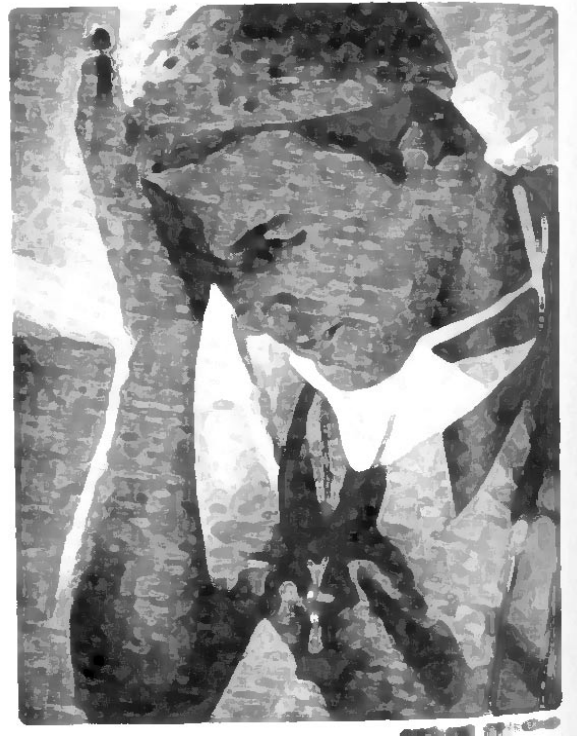

handlingsoppgavene. Særlig vaktarbeid og akuttberedskap tærer på kreftene og ser ut til å gi st $\varnothing r s t$ problemer for kvinnelige leger. Økende arbeidspress, krav fra publikum og liten toleranse for ikke å yte optimalt eller for å gjøre feil bidrar også til en negativ utvikling for mange. Blant leger har det vært lite åpenhet for å snakke om belastningene - de har til dels vært benektet. Dette er i ferd med å endres, kanskje nettopp fordi stadig flere kvinner kommer inn i yrkesgruppen med sitt bidrag til å få belyst og problematisert forholdene.

Det er tydelig at helsepersonell har begynt med seg selv når de har villet studere sammenhengen mellom yrke og selvmord. På dette feltet er litteraturen relativt fyldig. Men også andre yrkesgrupper er studert. Av grupper som har fått påvist forhøyet selvmordsrate, kan vi blant annet nevne sjøfolk i Norge og Finland, skogsarbeidere i Norge, politifolk i Australia og USA og gårdbrukere i England og USA. Fra tidligere tider har militært personell blitt regnet som en høyrisikogruppe for selvmord i flere land. Det militære selvmordet har tradisjonelt blitt beskrevet som utløst av nederlag og tap av ære og sosial prestisje. Det er liten tvil om at slike selvmord fortsatt forekommer. Men i de senere år er det blitt fokusert mer på risikofaktorer i form av mer ordinært jobbstress, hyppige flyttinger og konsekvenser av organisasjonsendringer. Dessuten har man fokusert på rekruttene som en risikogruppe for selvmord. Men det har ikke vært mulig å påvise noen overhyppighet av selvmord blant militært personell generelt ut fra forskning de siste tiår. Snarere er selvmordsraten til dels betydelig lavere enn $i$ befolkningen sett under ett. Ett unntak: Både i Norge og andre land har man påvist $\varnothing \mathrm{kt}$ selvmordsrate hos tidligere deltakere i FNs fredsbevarende operasjoner. Ut over de epidemiologiske studier som her er referert, finnes det en $1 \varnothing \mathrm{dig}$ forskningslitteratur som viser sammenhengen mellom faktorer knyttet til yrke og arbeidsplass og utvikling av psykiske og sosiale vansker, stressrelaterte lidelser, utbrenthet og rusmisbruk, og dette er velkjente risikofaktorer for selvmord.

\section{Forhold på arbeidsplassen}

Flere forhold ved arbeidet kan være årsak eller medvirkende årsak til selvmord og selvmordsfors $\varnothing$ k. Her vil vi gå inn på forandringer $i$ arbeidet og belastninger over tid, spesielt mobbing og forhold som fører til utbrenthet. Sterke traumatiske opplevelser i arbeidet, som vold, ran og ulykker blir omtalt i en egen artikkel i dette nummeret av Suicidologi.

\section{Omstilling}

Mange vil oppleve oppsigelse eller omorganisering som en stor belastning. Andre omstillinger i arbeidet kan også oppleves belastende, f.eks. forandring av arbeidsoppgaver eller arbeidssted, eller det å komme tilbake i arbeid etter lengre tids fravær. Det er stort behov for informasjon i slike situasjoner. Mange vil dessuten være spesielt sårbare i slike faser. Det er viktig å planlegge og styre prosessen på en slik måte at de ansatte føler seg tatt vare på og får medvirke.

Utenforliggende forhold vil også kunne ha betydning for hvordan en takler slike forandringer, bl.a. arbeidsmarked og konsekvenser for $\varnothing$ konomi og familie, identifikasjon med jobben, tap av ære, personfokusering og skyldplassering i media. 
Det er forsket lite på hvilken innflytelse omstillingsprosesser har på den enkeltes psykiske helse. Men vi vet at krenkelser av selvfølelsen, sosial marginalisering, tap av mening og håp og økonomiske vansker, som er mulige konsekvenser av omstillingsprosesser på arbeidsplassen, er risikofaktorer for selvmord. Vi trenger mer forskning på dette området, og i den senere tid er det blitt satt i gang konkrete prosjekter.

\section{Virkningene av langvarige belastninger}

Når arbeidstakere påvirkes av uheldige psykososiale belastninger over lang tid og når flere faktorer adderes, kan totaleffekten bli $\varnothing$ kende risiko for psykisk lidelse eller selvmord.

\section{Mobbing}

En mobbesituasjon har vi når noen gjentatte ganger over tid blir utsatt for negative handlinger (f.eks. trakassering, plaging, utfrysing eller sårende fleiping og erting) fra andre, og det er en ubalanse i styrkeforholdet mellom de to parter.

Som oftest dreier det seg om "hverdagslige handlinger" som skjer systematisk og over tid. Det er ikke bare de objektive hendelser eller handlinger som er viktige, men også den subjektive opplevelsen (Einarsen m.fl. 1994, Graversgård 1997).

I følge Levekårsunders $\varnothing$ kelsen om arbeidsmiljø fra 1996 svarte $2 \%$ av arbeidstakerne at de ble utsatt for plaging eller ubehagelig erting av arbeidskamerater e.l., og tallet var likt for kvinner og menn. $4 \%$ av kvinnene (6\% i alderen 25-44 år) og $1 \%$ av mennene (3\% i alderen 16-24 år) svarte at de ble utsatt for uønsket seksuell oppmerksomhet, kommentarer e.l.

Mobbing kan forekomme på alle nivåer i en organisasjon, og det kan skje både mellom medarbeidere på samme nivå, og mellom leder og underordnet. I noen yrker kan en dessuten bli mobbet av andre personer, som elever, klienter, kunder eller pasienter.

Mobbing kan ha flere årsaker og sannsynligvis skjer det et samspill mellom personfaktorer og situasjonsfaktorer.

Personfaktorer kan bl.a. være atferd, handlinger, personlighet, posisjon eller gruppetilhørighet. Det finnes avvik som blir brukt i mobbingen, men dette betyr ikke at avviket er årsak til mobbingen. De færreste av oss er som "alle andre" på alle områder, uten at vi dermed blir mobbet. Situasjonsfaktorer kan være arbeidsmiljøbelastninger i form av rollekonflikt, rolleuklarhet, uløste konflikter eller maktkamp, noe som kan føre til mye frustrasjon, lav solidaritet og "syndebukkmentalitet".

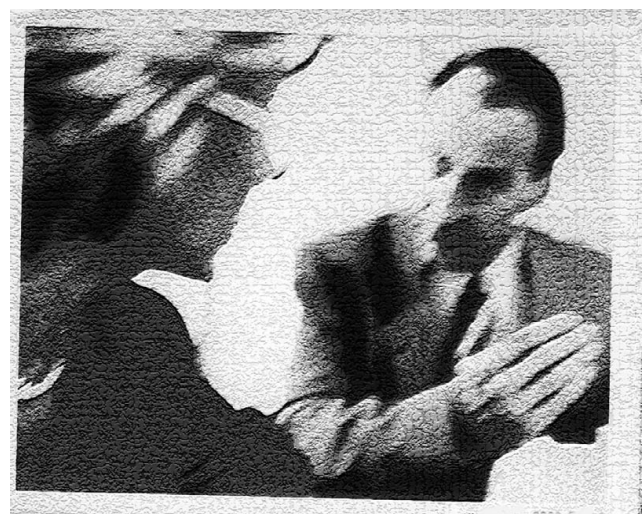

Det er funnet sammenhenger mellom mobbing og psykisk og fysisk helse, bl.a. depresjon, angst, muskel/skjelettplager og svakere generell helse. Mobbing virker psykisk nedbrytende, selvrespekten krenkes, og det blir vanskelig å bevare identitet og selvtillit. Det finnes ikke sikre tall på konsekvensene av mobbing, men det har vært gjort fors $\varnothing \mathrm{k}$ på å foreta beregninger. I Sverige er det anslått at mobbing på jobben har sammenheng med mellom 10000 og 30000 langtidssykmeldinger og mellom 100 og 300 selvmord årlig, 2-5 ganger så mange som antall dødsfall i arbeidsulykker (SOU 1999). Dersom dette skulle være holdbare tall, ville det tilsvare 50-150 selvmord i Norge årlig. Vi har imidlertid for lite kunnskap på feltet, og det er stort behov for forskning som kan kaste mer lys over forholdene.

Mobbing er et arbeidsmiljøproblem som berører flere enn mobber og offer. Det er et lederansvar å forebygge og stoppe alle former for mobbing, og det er påvist en sammenheng mellom ledelsens holdning til mobbing og utbredelse av mobbing i organisasjonen (Hytten 1988). Et godt arbeidsmiljø med åpen kommunikasjon, hvor konflikter blir håndtert raskt og på en god måte, vil forebygge mobbing. Ledelsen $b \varnothing r$ tydelig vise at mobbing ikke blir akseptert. Sosial st $\varnothing t t e$ til den som mobbes, vil dessuten kunne dempe effekten av mobbingen.

\section{Utbrenthet}

Utbrenthet medfører følelsesmessig utmattelse, et upersonlig syn på andre mennesker og en negativ vurdering av egen innsats (WHO, Graversgård 1994). Ârsakene har både med selve yrket, organiseringen av arbeidet og individuelle faktorer å gjøre. Helse- og omsorgsyrker og andre med nær følelsesmessig kontakt med mennesker er spesielt utsatt. Lignende tilstander kan sannsynligvis også forekomme i andre yrker med betydelig stress over lang tid.

Ofte finnes uklare eller motsetningsfylte mål og små ressurser i forhold til målene. Vanlig er også manglende kontroll over egen arbeidssituasjon, liten sosial st $\varnothing t t e$ i arbeidsmiljøet, manglende ledelse, supervisjon og opplæring og lite strukturert arbeid. Personer med urealistiske mål og forventninger, sterk identifikasjon med arbeidet og lav selvfølelse er spesielt utsatt. Den subjektive opplevelsen av arbeidet er av større betydning for utvikling av utbrenthet enn de objektive arbeidsforholdene.

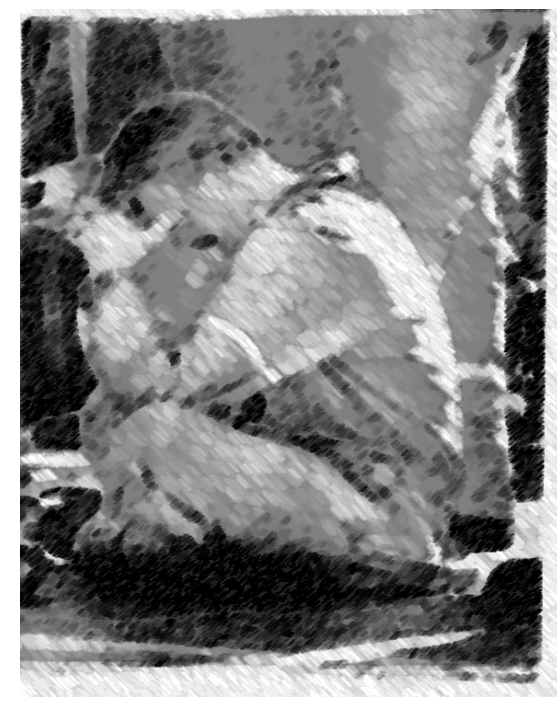

Utbrenthet kan forebygges både ved tiltak på organisjonsplanet og på individplanet. På organisasjonsplanet kan tilføring av mer ressurser ofte være en løsning, men mer realistiske mål og bedre organisering av arbeidet er minst like viktig. Forandringer i arbeid og arbeidsoppgaver kan redusere stress, f.eks. fordeling av belastende arbeid, variasjon $\mathrm{i}$ arbeidet og tid til reelle pauser og egenutvikling. De ansatte bør ha innflytelse på organiseringen av arbeidet og de forandringer som giøres, og overtidsarbeid bør begrenses. 
Fullstendig litteraturliste kan fås ved Seksjon for selvmordsforskning og -forebygging, tlf.: 229234 73, faks. 22923958 .

Internett: http://www.med.uio.no/ ipsy/ssff/9903mehlumarbeid.htm

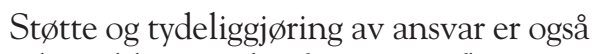
viktig, likeså god informasjonsflyt og rutiner for kartlegging av arbeidsmiljøet og for problemløsing. Mange har gode erfaringer med kollegast $\varnothing$ ttegrupper og andre fora hvor en kan få sosial st $\varnothing t t e$, diskutere utførelse av arbeidet og få veiledning fra mer erfarne kolleger.

Der det finnes få muligheter for kontroll over egen arbeidssituasjon, står en igjen med tiltak på individplanet, spesielt mestringsstrategier, og disse kan gå parallelt med de organisasjonsmessige tiltak. Aktuelle strategier er å arbeide mer effektivt, planlegge og variere arbeidet og sette av tid til pauser. Mål og ansvar bør avklares og bør være realistiske, både for organisasjonen og for den enkelte. Egenomsorg er ellers viktig, med respekt for egne grenser og tid og mulighet til hvile og avkobling og et eget liv utenom jobben.

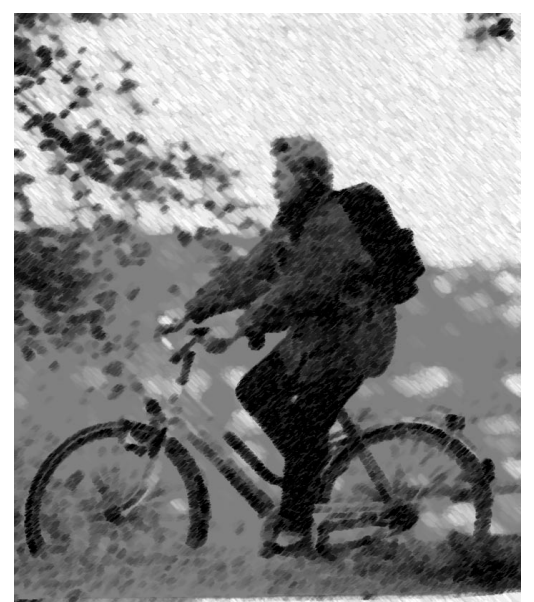

Flere forhold har betydning for opplevelsen av stress i arbeidet. Arbeidets krav og kontroll over arbeidssituasjonen er to av disse. Dersom det stilles høye krav og man har liten kontroll, vil arbeidet oppleves mer stressende enn dersom kravene er lavere eller kontrollen høyere. Opplever en sosial støtte på arbeidsplassen eller privat, kan en tåle større belastninger enn om slik st $\varnothing$ tte mangler. Hvis en opplever at arbeidet er meningsfylt og at det en gjør er viktig, vil en også kunne tåle mer.

\section{Forhold utenfor arbeidsplassen}

Selv om årsakene til selvmord ligger utenfor arbeidsplassen, vil slike forhold ofte gå utover arbeidet som skal utføres, for eksempel ved fysisk eller psykisk syk- dom, rusmisbruk eller familieproblemer. Da er ikke slike private forhold bare en privatsak, men også en sak for bedriften, og arbeidsgiver har både rett og til dels også plikt til å ta opp saken med utgangspunkt i de forandringer som får konsekvenser for arbeidet. To spørsmål er viktige:

- Har forandringene noe med arbeidet å gjøre - er det forhold ved arbeidet som virker belastende?

- Uansett hvor årsaken ligger - kan noe gjøres for å legge arbeidsforholdene til rette slik at den totale belastningen blir mindre?

Arbeidsmiljøloven krever at arbeidsgiver skal følge opp slike forhold. Nærmeste leder er den som best kan fange opp forandringer og ta det opp på et tidlig tidspunkt, uten at det bærer preg av å være en stor og alvorlig sak, men mer et uttrykk for interesse og omsorg. Arbeidsmiljøloven krever dessuten at arbeidsgiver skal tilrettelegge arbeidet under hensyn til den enkelte arbeidstakers alder, kyndighet, arbeidsevne og $\varnothing$ vrige forutsetninger, noe som er viktig for at eldre og yrkeshemmede skal kunne være i arbeidslivet.

Retningslinjer for håndtering og oppfølging av slike saker vil være en naturlig del av det systematiske helse-, milj $\varnothing$ - og sikkerhetsarbeid (HMS-arbeid) som alle bedrifter har plikt til å ha. Det kreves at en skal kartlegge arbeidsmiljøproblemer, foreta risikovurdering av disse, utarbeide handlingsplaner og iverksette forebyggende tiltak. Dette gjelder ikke bare for det fysiske arbeidsmiljøet, men også psykososiale og organisatoriske forhold. Arbeidsgiver har ansvaret for at dette gjøres, men arbeidstakerne har både rett og plikt til å medvirke.

Mye kan gjøres for å forebygge sykdom og plager blant de ansatte, og enkelte bedrifter har begynt å gå lenger enn det som hittil har vært vanlig, kanskje først og fremst for å $\varnothing$ ke produktiviteten og gjøre de ansatte mer tilgjengelige for bedriften. Mange har satt i gang arbeid for å forebygge rusmiddelmisbruk og sykefravær: Noen går inn for å forebygge familieproblemer og samlivsbrudd, og enkelte går så langt at de tilbyr barnevaktordninger, hushjelptjenester og mulighet for fjernarbeid (hjemmearbeid). Dette gir $\varnothing \mathrm{kt}$ fleksibilitet for de ansatte. En uheldig konsekvens kan imidlertid bli at arbeid og fritid går for mye i ett.

\section{Avslutning}

Etter hvert som mange har fătt et fjernere forhold til familie og nærmilj $\phi$, har arbeidsplassen for mange overtatt som den viktigste sosiale arena utenfor hjemmet. Arbeidsplassen er derfor et viktig sted for forebyggende innsats blant den voksne befolkning. Men også der skjer det en sosial oppløsning. Moderne dataog kommunikasjonsteknologi gir oss arbeidsplasser som er mindre avhengige av tid og sted. Mye av arbeidet kan gjøres hvor som helst og når som helst. Utnyttet på en god måte vil dette kunne skape arbeidsplasser i utkant-Norge, og folk vil kunne bli boende der de har sin sosiale tilhørighet. Men den samme teknologien kan også føre til tap av sosial kontakt på arbeidsplassen og $\varnothing \mathrm{kt}$ grad av fremmedgjøring.

Det er en utfordring for dagens arbeidsgivere å tenke lenger enn produktivitet og фkonomi på kort sikt. Det er viktig å ta hensyn til de ansattes behov for sosial tilhørighet, bl.a. for å forebygge utbrenthet, psykiske lidelser og selvmordsatferd, men også av hensyn til produktivitet og $\varnothing$ konomi på lengre sikt. Det kan lønne seg å ta vare på sosiale sammenhenger og holde fast ved de ressurser som ligger i arbeidsgrupper og en god bedriftskultur.

Forts. side 20
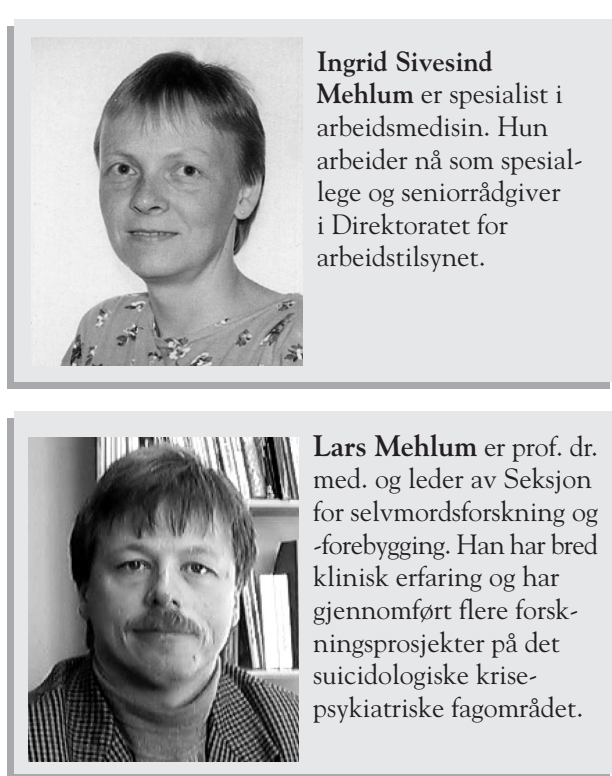


\section{Litteratur}

Einarsen S, Raknes BI, Mathisen SB, Hellesøy OH. Mobbing og harde personalkonflikter - helsefarlig samspill på arbeidsplassen. Bergen: Sigma, 1994.

Graversgård, J. Udbrændthed - bryd den onde cirkel. København: Frydenlund, 1994.

Graversgård, J. Psykisk arbeidsmilj $\phi$ - en veiledning. Oslo: Tiden, 1997.

Hytten K. A study of bullying in the military. Ann Med Milit Fenn 1988:63:144.

Mehlum IS, Mehlum L. Arbeidsplassen - en ny arena for forebygging av selvmord. I: Mehlum L (red.) Tilbake til livet. Selvmordsforebygging i teori og praksis. Kristiansand: Høyskoleforlaget, 1999.

Mehlum L. Forebyggelse av selvmord i Forsvaret. Utredning fra ekspertgruppe oppnevnt av Forsvarets Overkommando. Oslo: Forsvarets Overkommando, 1993.

SOU 1999:69. Individen och arbetslivet - perspektiv på det samtida arbetslivet kring sekelskiftet 2000 . WHO. Staff burnout. Internett:

http://www.who.int/msa/mnh/mnd/prev.htm\#burnout

\section{Forts. fra side 13 (Krisehåndtering)}

\section{Avslutning}

Vi har i dag mye kunnskap om hvordan en kan forebygge traumatiske opplevelser og senreaksjoner etter slike hendelser. Mange bedrifter har gode rutiner på dette området, men altfor mange har ikke tenkt igjennom problemstillingen f $\varnothing \mathrm{r}$ den plutselig dukker opp. Mye kunne vært gjort på forhånd, både for å forebygge selve hendelsen og for å sikre de berørte en

\section{Selvmordsforsøk, fall i hyppighet før og under høytidsdager, økning etterpå}

Hensikten med arbeidet var å undersøke sammenhengen mellom selvmordsfors $\varnothing \mathrm{k}$ og større høytidsdager i Europa. Materialet bygger på data fra 24388 selvmordsfors $\varnothing \mathrm{k}$ i perioden 1989-1996. 13

europeiske sentre deltok i unders $\varnothing$ kelsen. Det ble funnet et klart fall i hyppigheten av selvmordsfors $\varnothing \mathrm{k}$ f $\varnothing \mathrm{r}$ og under en høytid, men $\varnothing$ kning etterpå. Man taler om "broken-promise effect". Dette gjaldt spesielt de store høytider som jul, påske og pinse.

Jensen G, Jensen BF, Arensman E, Bille-Brahe U, Crepet P, DeLeo D, Hawton K, Harring C, Hjelmeland H, Michel K, Ostamo A, SalanderRenberg E, Schmidtke A, Tamesvary B, Wasserman D: Attempted suicide and major public holidays in Europe: findings from the WHO/EURO Multicentre Study on Parasuicide. Acta Psychiatr. Scand. 1999; 99: 412-418.
Forts. fra side 15 (Arbeidsplassen)

Dette gjeld dysfunksjonelle kostnader i form av mindre samhald, kollegast $\varnothing$ tte, heilskapskjensle - med andre ord færre felles haldepunkt å forankre negative så vel som positive opplevingar i. Ei slik utvikling vil vere uheldig $i$ alle fasar $i$ vårt organisasjonsliv, men ikkje minst $\mathrm{i}$ periodar der vi er psykisk sårbare. Kven skal erstatte kollegaene når vi sit på heimekontoret med stadig større psykiske vanskar? I kva grad er moderne organisasjonar med høgt tempo og stadige endringar tilpassa eldre arbeidstakarar? Er det iverksett nok individtilpassa tiltak retta mot alle dei som av ulike årsaker ikkje lenger maktar stresset og presset i arbeidslivet? Vil det å delta i moderne organisasjonsformer bli for $t \varnothing f t$ for stadig fleire, og då særleg for dei av oss som har tunge bører av fysisk eller psykisk art å bære på i tillegg? Er vi i dag så framandgjorde for kvarandre at vi blir fråtekne høve, evne og vilje til å sjå og gripe inn i medarbeidarar sine psykiske problem? I så fall blir det viktigare enn nokon gong å danne ein arbeidskultur med låge tersklar for sjølv å kunne synleggjere sine problem, og der dette medfører forståing og respekt framfor sanksjonar.

Truleg vil postmoderne former å organisere arbeidet og arbeidsdagen på innverke på dei tilsette si psykiske helse "annleis" enn tidlegare (Sørensen m.fl. 1998). I så fall vil vi oppleve at tradisjonelle førebyggingstiltak på arbeidsplassen vil ha stadig mindre effekt.

\section{Litteratur:}

Bjørge MK. Arbeidsplassen - en god st $\phi$ tte i sorg. Sammendrag. Rapport frå NHO Arbeidsmiljøfondet og Arbeidsmiljøsenteret. Ålesund 1997.

Durkheim É. Selvmordet. Oslo: Gyldendal, 1978

Hammerlin Y, Enerstvedt R. Selvmord.

Oslo: Falken forlag, 1988.
Svanstrøm R. Knudsen H. Trusler og vold i arbeidslivet. Oslo: Folkets Brevskole, 1997.

Weisæth L. Stress reactions to an industrial disaster. Oslo: Division of Disaster Psychiatry, Institute for Psychiatry Gaustad, The Psychiatric Institute Vindern, University of Oslo, The Joint Norwegian Armed Forces Medical Service, 1984.

Weisæth L, Mehlum L (red.). Mennesker, traumer og kriser. Oslo: Universitetsforlaget, 1993.

Fullstendig litteraturliste kan fås ved Seksjon for selvmordsforskning og -forebygging, tlf.: 22923474 , faks 229239 58. Internett: http://www.med.uio.no/ ipsy/ssff/9903mehlumkrise.htm

Hauge NP, Hammerlin Y. Selvmordsforebygging i et helhetlig perspektiv. I Mehlum L, red. Tilbake til livet. Selvmordsforebygging i teori og praksis. Kristiansand: Høyskoleforlaget, 1999.

Lukacs G. Tingliggjøringen og proletariatets bevissthet. I Østerberg D, red. Handling og samfunn. Sosiologisk teori i utvalg. Oslo: Pax, 1978.

Sørensen BA, Rapmund A, Fuglerud KS, Hilsen AI, Grimsmo A. Psykologiske, organisatoriske og sosiale faktorer $i$ arbeid av betydning for helse: kunnskapsmangler og forskningsbehov. AFIs rapportserie. Oslo: Arbeidsforskningsinstituttet 1998.(AFIs rapportserie; 8/98)

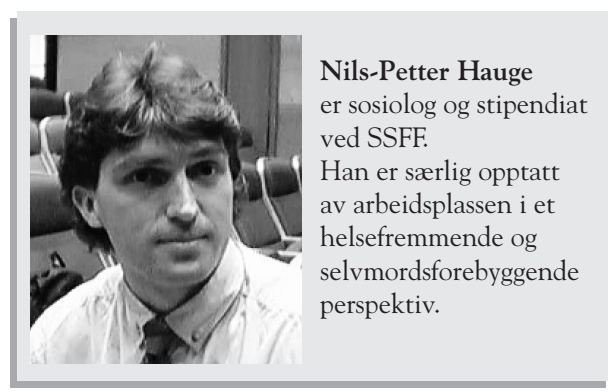

